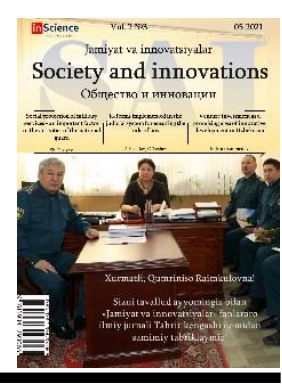

\title{
Anti-erosion technologies and technical means for tillage in the conditions of Uzbekistan
}

\author{
Shakhnoza BURANOVA ${ }^{1}$, Yunus TILAVOV², Zulpikar TUYMURADOV ${ }^{3}$ \\ Karshi State University
}

\begin{tabular}{l} 
ARTICLE INFO \\
\hline Article history: \\
Received April 2021 \\
Received in revised form \\
20 April 2021 \\
Accepted 15 May 2021 \\
Available online \\
15 June 2021 \\
\hline
\end{tabular}

Keywords:

water erosion,

soil,

moisture conservation,

technology,

plow-ripper,

paraplow,

slope.

\begin{abstract}
In the article, it is shown the necessity of the development of anti-erosion moisture-saving technical means of soil cultivation in the conditions of Uzbekistan. New technologies and technical means of soil cultivation are presented, contributing to the prevention of water erosion, the preservation and the accumulation of moisture in the arable layer.
\end{abstract}

2181-1415/C) 2021 in Science LLC.

This is an open access article under the Attribution 4.0 International (CC BY 4.0) license (https://creativecommons.org/licenses/by/4.0/deed.ru)

\section{0'zbekiston sharoitida eroziyaga qarshi texnologiya va shudgorlash uchun texnik vositalar}

\author{
Kalit so'zlar: \\ suv eroziyasi, \\ tuproq, \\ namlikni tejash, \\ texnologiya, \\ shudgorlash, \\ paraplov, \\ qiyalik.
}

\begin{abstract}
ANNATATSIYA
O'zbekiston sharoitida tuproqni etishtirishning eroziyaga qarshi namlikni tejaydigan texnik vositalarini yaratish zaruriyati ko'rsatilgan. Suv eroziyasining oldini olish, haydaladigan qatlamda namlikni saqlash va to'planishiga yordam beradigan yangi texnologiyalar va tuproqni etishtirishning texnik vositalari namoyish etilmoqda.
\end{abstract}

\footnotetext{
${ }^{1}$ Lecturer of the department of technological education, Karshi State University. Karshi, Uzbekistan.

E-mail: umidshah@bk.ru.

$2 \mathrm{PhD}$, Senior Lecturer of the Department of Technological Education, Karshi State University, Karshi, Uzbekistan.

E-mail: tilavov56@mail.ru.

${ }^{3} \mathrm{PhD}$, Senior Lecturer of the Department of Technological Education, Karshi State University. Karshi, Uzbekistan.

E-mail: tuymuradov.z@mail.ru.
} 


\section{Антиэрозионные технологии и технические средства для почвы в условиях Узбекистана}

\author{
Ключевые слова: \\ водная эрозия, \\ почва, \\ влагосбережение, \\ технология, \\ плуг-рыхлитель, \\ параплау, \\ склон.
}

\begin{abstract}
АННОТАЦИЯ
Показана необходимость разработки противоэрозионных влагосберегающих технических средств обработки почвы в условиях Узбекистана. Приведены новые технологии и технические средства обработки почвы, способствующие предотвращению водной эрозии, сохранению и накоплению влаги в пахотном слое.
\end{abstract}

\section{INTRODUCTION}

The soil and climatic conditions of Uzbekistan make it possible to obtain highquality crop products. However, the lack of soil moisture and the unstable nature of moisture constrain the growth of agricultural production, especially in rainfed agriculture. A feature of the climate is a low amount of precipitation, frequent recurrence of long periods without rain (droughts), and strong hot winds that systematically occur at low relative humidity and high air temperatures. The deficit of productive moisture is caused not only by the lack of atmospheric precipitation but also by their irrational use.

It should be recognized that the existing system of machines for plant growing, created mainly for optimal soil and climatic conditions, does not meet the requirements for the most complete accumulation and conservation of soil moisture. As a result, more than $70 \%$ of the cultivated area in Uzbekistan is, to one degree or another, subject to water erosion. Water erosion is strongly manifested on slopes with finely cultivated soil, especially during heavy rains [14-17].

In the system of agrotechnical methods, the main moisture-saving role is assigned to methods of soil cultivation, which should ensure the most complete accumulation of moisture from atmospheric precipitation in the root layer and prevent its evaporation through the treated soil layer. Therefore,to prevent water runoff and soil washout it is necessary to apply special anti-erosion soil cultivation technologies [6-9, 14-16].

The purpose of the study is to substantiate the need for the development and implementation of anti-erosion technologies and technical means for soil cultivation in Uzbekistan.

\section{MATERIALS AND METHODS}

The basic principles and methods of classical mechanics, mathematical analysis, and statistics were used in this study.

\section{RESEARCH RESULTS}

It is known that one of the most effective moisture-saving technologies is loosening the topsoil while preserving stubble and other crop residues on its surface. Such a wellloosened soil layer mulched with plant residues prevents capillary evaporation of moisture from the underlying layers and allows more preservation of residual soil moisture reserves. A moisture-protective layer in an ideal form can be created by a tillage cutter that performs fine crumbling loosening of the soil, complete cutting of weeds, embedding their seeds, as well as good crushing of plant residues. 
The most realistic and quite effective technology is loosening the topsoil with crushing plant residues with a simultaneous loosening of the arable layer and rolling. The combination of these operations can be carried out with a combined tool (Fig. 1a), consisting of active working bodies in the form of a cutter, flat-cutting working bodies, and a support-leveling roller installed behind them. The latter provides additional crumbling, pressing stubble to the soil surface, leveling, and compaction of the loosened soil layer. The combination of the work of the roller and flat-cutting bodies improves their stability at a small depth. After the passage of such a combined plow-ripper, $85-95 \%$ of plant residues remain on the soil surface, which significantly reduces the evaporation of soil moisture $[3,8,15]$.

Ripper-plow [17, 18], equipped with 1 and 2 different-sized working bodies of the "paraplow" type (Fig. 1b). When the cultivator is working, the bottom of the cultivated field is stepped, which allows the retention and accumulation of soil moisture and the elimination of subsurface erosion on sloping lands. Depending on the steepness of the slope, the distance between the cut grooves can be changed by placing the lower working bodies 2 through several upper working bodies 1 . If necessary, the working bodies 2 with a higher height can be equipped with dumps 3 [18]. When such a tool is operating on slopes, a stepped bottom of the furrow with a periodic deepening (subsoil ridges), intersecting the compacted bottom and surface ridges, is obtained (Fig. 1c).
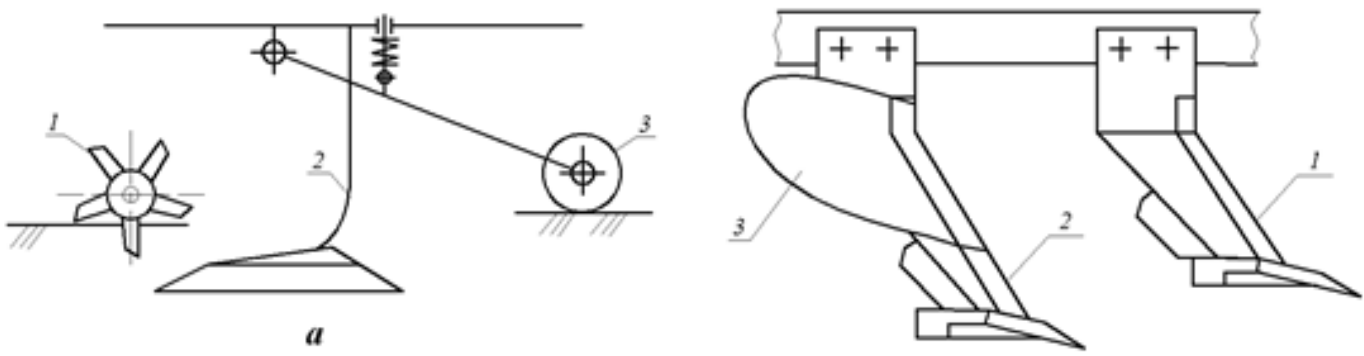

$b$
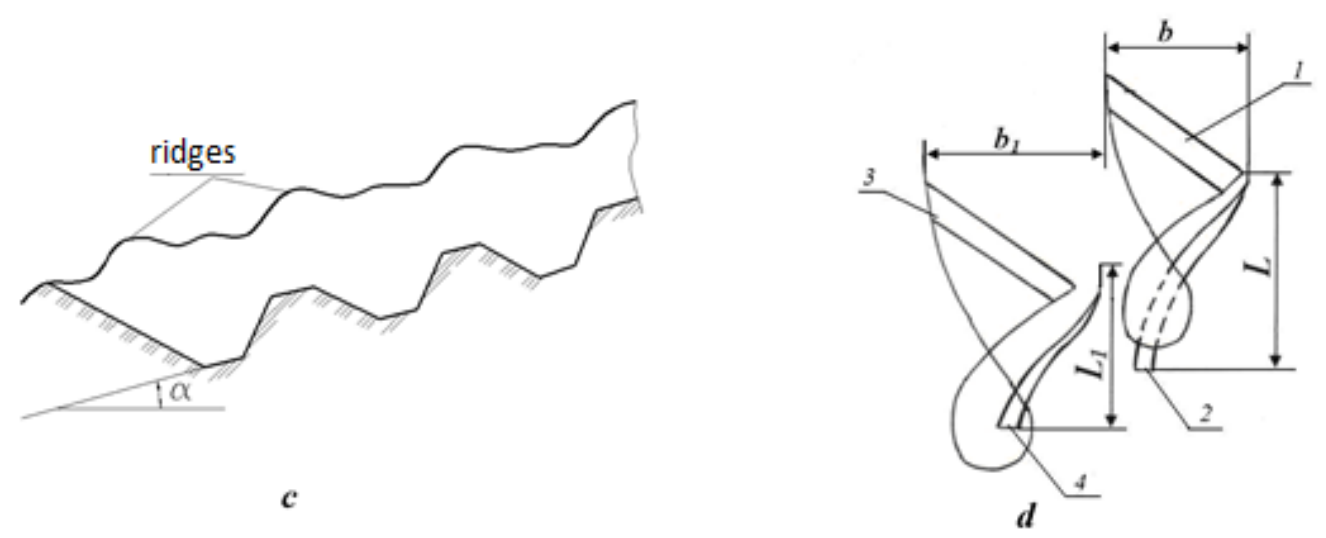

Fig. 1. Schemes of tools for the implementation of moisture-saving technologies: a) a ripper with active and passive working bodies; b) a two-level plow-ripper with moldboard and moldboardless working bodies of the "paraplow" type; c) cross-section of a field processed by a two-tier ripper plow with moldboard and moldboardless working bodies; d) a plow for stepped plowing.

In the developed plow for smooth-stepped plowing [1-3], bodies 1 and 3 are located with an offset relative to each other, on which guide plates 2 and 4 are installed with working surfaces facing the screw plowshare-moldboard surfaces of the bodies (Fig. 1, d). 
Even bodies 3 are made with a greater height $\mathrm{H}_{1}$ and a capture width $\mathrm{b}_{1}$, and an odd body 1 with a lower height $\mathrm{H}$ and a capture width $\mathrm{b}$. The capture width of the even body 3 is equal to $b_{1}=b+K\left(\mathrm{H}_{1}-\mathrm{H}\right)$, where $\mathrm{H}$ is the height of the odd bodies; $\mathrm{H}_{1}$ - the height of the even buildings; $\mathrm{K}$ is a coefficient that takes into account the ratio of the width of the body to the depth of processing.

The length of the guide plate 4 of the even bodies 3 is less than the length of the guide plate 2 of the odd bodies 1 by $0.25 \mathrm{~L}$, i.e. $\mathrm{L}_{1}=0.75 \mathrm{~L}$, where $\mathrm{L}$ is the length of the guide plate of the odd body.

When the plow is working across the slope, the body 1 with a lower height $\mathrm{H}$ and a working width $b$, penetrating the soil, separates a layer of thickness a1 from the bottom of the furrow and, interacting with the guide plate 2 , wraps it $180^{\circ}$ into its furrow. Then, the housing 3 with a greater height $\mathrm{H}_{1}$ and a working width b1 separates the layer with a thickness of $\mathrm{a}_{2}$ from the bottom of the furrow and, interacting with the short guide plate 4 , wraps it by $135^{\circ}$. After the passage of the plow, a stepped bottom of the furrow and a ridged surface of arable land is formed. The combination of the stepped bottom of the furrow with the ridged surface of the arable land contributes to the retention of water and the exclusion of soil washout after heavy rainfall.

\section{FINDINGS}

1) Protection of the soil of slopes from wind and water erosion, improvement of quality indicators of basic tillage, reduction of its energy intensity can be achieved through the introduction of new technologies and technical means of soil cultivation.

2) Applications a ripper with active and passive working bodies, a two-tier plowripper with moldboard and plowless working bodies of the "paraplow" type, and a plow for smooth-step plowing help prevent water erosion, preserve and accumulate moisture in the soil.

\section{REFERENCES:}

1. Mirzaev B, Mamatov F, Tursunov O. A justification of broach-plow's parameters of the ridge-stepped plowing https://doi.org/10.1051/e3sconf/20199705035.

2. Mirzaev B, Mamatov F, Avazov I, Mardonov S. Technologies and technical means for anti-erosion differentiated soil treatment system E3S Web of Conferences. https://doi.org/10.1051/e3sconf/20199705036.

3. Mirzaev B, Mamatov F, Ergashev I, Ravshanov H, Mirzaxodjaev Sh, Kurbanov Sh, Kodirov $\mathrm{U}$ and Ergashev G. Effect of fragmentation and pacing at spot ploughing on dry soils E3S Web of Conferences 97 https://doi.org/10.1051/e3sconf/201913501065.

4. Mirzaev B, Mamatov F, Chuyanov D, Ravshanov X, Shodmonov G, Tavashov R and Fayzullayev X. Combined machine for preparing soil for cropping of melons and gourds XII International Scientific Conference on Agricultural Machinery Industry. doi.org/10.1088/ $1755-1315 / 403 / 1 / 012158$.

5. Mirzaev B, Mamatov F, Aldoshin N and Amonov M. Anti-erosion two-stage tillage by ripper Proceeding of 7 th International Conference on Trends in Agricultural Engineering 17th-20th September (Prague Czech Republic) - pp 391-396.

6. Umurzakov U Mirzaev B Mamatov F Ravshanov H Kurbonov S. A rationale of broach-plow's parameters of the ridge-stepped plowing of slopes 403 (1) International Scientific Conference on Agricultural Machinery Industry https://www.scopus.com /sourceid/19900195068. 
7. Aldoshin N., Mamatov F., Ismailov I., Ergashov G. Development of combined tillage tool for melon cultivation // 19th international scientific conference engineering for rural development Proceedings, Volume 19 May 20-22, 2020. ISSN 1691-5976.

8. Mamatov F., Ergashev I., Ochilov S., Pardaev X. Traction Resistance of Soil Submersibility Type "Paraplau" // Jour of Adv Research in Dynamical \& Control Systems, Vol. 12, 07-Special Issue, 2020. DOI: 10.5373 / JARDCS / V12SP7 / 20202336. ISSN 1943-023X.

9. Mamatov F., Mirzaev B., Batirov Z., Toshtemirov S., Tursunov O., Bobojonov L. Justification of machine parameters for ridge forming with simultaneous application of fertilizers // CONMECHYDRO - 2020. IOP Conf. Series: Materials Science and Engineering 883 (2020) 012165.doi: 10.1088 / 1757-899X / 883/1/012165.

10. Aldoshin N.V., Mamatov F.M., Ismailov I.I. Unit for soil preparation for melons and gourds // Bulletin of the St. Petersburg State Agrarian University. Quarterly scientific journal. - No. 2 (59). - P. 141.

11. Kodirov U., Aldoshin N., Ubaydullayev Sh., Sharipov E., Muqimov Z and Tulaganov B. The soil preparation machine for seeding potatoes on comb // Materials Science and Engineering, 2020. CONMECHYDRO - 2020. doi: 10.1088 / 1757-899X / 883/1/012143.

12. Ravshanov Kh., Fayzullaev Kh., Ismoilov I., Irgashev D., Mamatov S. The machine for the preparation of the soil in sowing of plow crops under film // International scientific conference "Construction mechanics, hydraulics and water resources engineering" CONMECHYDRO - 2020. - Tashkent, 2020.doi: 10.1088 / 1757-899X / 883/1/012138.

13. Ravshanov H, Babajanov L, Kuziev Sh, Rashidov N, Kurbanov Sh. Plow hitch parameters for smooth tails // International scientific conference "Construction mechanics, hydraulics and water resources engineering" CONMECHYDRO-2020. Tashkent, 2020. doi: 10.1088 / 1757-899X / 883/1/012139.

14. Chuyanov D., Shodmonov G., Avazov I., Rashidov N, Ochilov S. Soil preparation machine parameters for the cultivation of cucurbitaceous crops // International scientific conference "Construction mechanics, hydraulics and water resources engineering" CONMECHYDRO-2020. - Tashkent, 2020. doi: 10.1088 / 1757-899X / 883/1/012122. 